\title{
Mobile Learning in Higher Education: Unavoidable Alternative during COVID-19
}

\author{
Aziz Naciri ${ }^{1 *}$, Mohamed Amine Baba ${ }^{2}$, Abderrahmane Achbani ${ }^{2,4}$, Ahmed Kharbach ${ }^{2,3}$
}

\author{
${ }^{1}$ High Institute of Nursing Professions and Technical Health, Laâyoune, MOROCCO \\ ${ }^{2}$ High Institute of Nursing Professions and Technical Health, Agadir, MOROCCO \\ ${ }^{3}$ Laboratory of Biostatistics, Clinical Research and Epidemiology (LBRCE), Faculty of Medicine and Pharmacy of Rabat, MOHAMED V University of Rabat, MOROCCO \\ ${ }^{4}$ Laboratory of Cell Biology and Molecular Genetics, Department of Biology, Faculty of Sciences, University Ibn Zohr, Agadir, 80000 MOROCCO \\ *Corresponding Author: Aziz.ncr@gmail.com
}

Citation: Naciri, A., Baba, M. A., Achbani, A., \& Kharbach, A. (2020). Mobile Learning in Higher Education: Unavoidable Alternative during COVID-19. Aquademia, 4(1), ep20016. https://doi.org/10.29333/aquademia/8227

\section{ARTICLE INFO}

Received: 28 Apr. 2020

Accepted: 30 Apr. 2020

\begin{abstract}
Covid-19 is an acute respiratory disease caused by Coronavirus Sars-Cov-2. Declared recently as pandemic disease, Covid-19 has affected educational systems worldwide. Many countries around the world have closed educational institutions to reduce the spread of this pandemic. Hence, Education in high schools is facing unprecedented challenges.
\end{abstract}

This paper reflects on the role of mobile learning as remote teaching strategies sustaining student-centered learning.

The use of mobile learning allows learning anytime, anyplace, and anywhere. Mobile Learning is an unavoidable alternative during COVID-19.

Keywords: mobile learning, coronavirus, pedagogical method

COVID-19 is an acute respiratory disease caused by Coronavirus Sars-Cov-2 (World Health Organization, 2020a). Since who declared COVID-19 as pandemic disease (World Health Organization, 2020b), Many countries worldwide have responded seriously to this pandemic. A battery of precautionary measures has taken to stop the spread of the virus. Hence, thousands of universities and colleges have been closed to encourage social distancing measures and thus limit the spread of the virus.

Under this pandemic, Educational institutions, are presented with surmounting challenges in its education system. the COVID-19 will have an impact on the educational provision. Hence, there will be a drop especially in national examinations (Sintema \& Education, 2020). This critical situation brings to light many concerns such as deterioration of the quality of education and the future of the students (Usak, Masalimova, Cherdymova, \& Shaidullina, 2020).

Then, there is a greater need for educational institutions to strengthen the practices in the curriculum and the use of innovative teaching techniques and approaches will be a paramount importance (Toquero, 2020).

Several research on mobile learning has been conducted in order to understand the use of mobile devices in educational settings (Sönmez, Göçmez, Uygun, Ataizi, \& Learning, 2018).
Indeed, mobile devices are becoming ubiquitous. This opportunity suggests that the use of mobile learning would be valuable for both students and teachers (Aubusson, Schuck, \& Burden, 2009).

Mobile Learning denote learning involving the use of a mobile device (Crompton, Burke, \& Education, 2018). It has several advantages and benefits. First, this teaching method can occur at anyplace, anytime, and anywhere and the learning process is not limited to one particular place (Corbeil \& Valdes-Corbeil, 2007). Besides, it allows teachers to personalize instruction (Steel, 2012) and allow students to self-regulate learning (Sha, Looi, Chen, \& Zhang, 2012).

Generally, mobile learning helps students to develop technological skills, conversational skills, find answers to their questions, develop a sense of collaboration, allow knowledge sharing, and hence leverage their learning outcomes (AlEmran, Elsherif, \& Shaalan, 2016).

The quick transition to E-learning went successful and gained experience can be used in the future. The lesson learned from the COVID -19 will force a generation of new laws, regulations, platforms and solutions for future cases (Basilaia \& Kvavadze, 2020).

The circumstances of confinement caused by the coronavirus, and to ensure continuity of teaching for students, 
mobile learning is an essential educational technology component in higher education. It makes it possible for students to learn, collaborate, and share ideas.

\section{ACKNOWLEDGEMENT}

The authors want to acknowledge the Editorial office of the journal and all the anonymous reviewers.

\section{REFERENCES}

Al-Emran, M., Elsherif, H. M., \& Shaalan, K. J. C. i. H. b. (2016) Investigating attitudes towards the use of mobile learning in higher education. Computers in Human Behavior, 56, 93102. https://doi.org/10.1016/j.chb.2015.11.033

Aubusson, P., Schuck, S., \& Burden, K. J. A.-J. (2009). Mobile learning for teacher professional learning: benefits, obstacles and issues. Research in Learning Technology, 17(3), 233-247. https://doi.org/10.3402/rlt.v17i3.10879

Basilaia, G., \& Kvavadze, D. (2020). Transition to Online Education in Schools during a SARS-CoV-2 Coronavirus (COVID-19) Pandemic in Georgia. Pedagogical Research, 5(4), em0060. https://doi.org/10.29333/pr/7937

Corbeil, J. R., \& Valdes-Corbeil, M. E. J. E. Q. (2007). Are you ready for mobile learning? Educause, 30(2), 51. Retrieved from https://er.educause.edu/articles/2007/4/are-youready-for-mobile-learning

Crompton, H., Burke, D. J. C., \& Education. (2018). The use of mobile learning in higher education: A systematic review. Computers \& Education, 123, 53-64. https://doi.org/10.1016/j.compedu.2018.04.007
Sha, L., Looi, C. K., Chen, W., \& Zhang, B. H. J. J. o. C. A. L. (2012). Understanding mobile learning from the perspective of self - regulated learning. Journal of Computer Assisted Learning, 28(4), 366-378. https://doi.org/10.1111/j.1365-2729.2011.00461.x

Sintema, E. J. (2020). Effect of COVID-19 on the Performance of Grade 12 Students: Implications for STEM Education. Eurasia Journal of Mathematics, Science and Technology Education, 16(7), em1851. https://doi.org/ 10.29333/ejmste/7893

Sönmez, A., Göçmez, L., Uygun, D., \& Ataizi, M. (2018). A review of current studies of mobile learning. Journal of Educational Technology and Online Learning, 1(1), 12-27. https://doi.org/10.31681/jetol.378241

Steel, C. (2012). Fitting learning into life: Language students' perspectives on benefits of using mobile apps. Paper presented at the Future challenges, sustainable future, Proceedings of ascilite conference Wellington 2012.

Toquero, C. M. (2020). Challenges and Opportunities for Higher Education amid the COVID-19 Pandemic: The Philippine Context. Pedagogical Research, 5(4), em0063. https://doi.org/10.29333/pr/7947

Usak, M., Masalimova, A. R., Cherdymova, E. I., \& Shaidullina, A. R. (2020). New playmaker in science education: COVID19. Journal of Baltic Science Education, 19(2), 180-185. https://doi.org/10.33225/jbse/20.19.180

World Health Organization. (2020a). Naming the coronavirus disease (COVID-19) and the virus that causes it. Retrieved on 22 April 2020 from https://bit.ly/2KHu29A

World Health Organization. (2020b). Statement on the meeting of the International Health Regulations (2005) Emergency Committee regarding the outbreak of novel coronavirus (2019-nCoV). Retrieved on 25 April 2020 from https://bit.ly/2RwodiW 